\title{
Mycorrhizal Association of Terrestrial Orchids of Cycloops Nature Reserve, Jayapura
}

\author{
VERENA AGUSTINI", SUPENI SUFAATI, SUHARNO \\ Biologi Department, Faculty of Mathematics and Natural Science, Cenderawasih University (UNCEN), Jayapura 99358, Papua \\ Received: $14^{\text {th }}$ December 2008. Accepted: $15^{\text {th }}$ June 2009.
}

\begin{abstract}
Study on exploration of mycorrhizal association of terrestrial orchid of Cycloops Nature Reserve, Jayapura was done. The aims of this study were to collect terrestrial orchid and to isolate orchid mycorrhiza associated with it. Survey method was used in this study. Isolation of orchid mycorrhiza was based on modified methods of Masuhara and Katsuya (1989). The result showed that there were 10 species of terrestrial orchid in this area. Eleven orchid mycorrhizal fungi were isolated from five terrestrial orchids. Among them, 6 isolates were associated with Geodorum sp. From the seventeen mycorrhizal fungi, 3 isolates were identified, namely Rhizoctonia sp., Tulasnella sp., and Ceratorhiza sp, while the last fourteen isolates have not been identified yet. Mostly, each isolate has a specific orchid host, except species G (sp. G) which associated with Phaius sp. and Plocoglottis sp.
\end{abstract}

(C) 2009 Biodiversitas, Journal of Biological Diversity

Key words: terrestrial orchid, orchid mycorrhiza, Mt. Cycloops Nature Reserve, Jayapura.

\section{INTRODUCTION}

Papua contains very high level of plant diversity. It may have at least 20.000-25.000 species of vascular plants including orchids. 3000 species of orchids are found in Papua, mostly are epiphytic. The exploration of orchids in Papua remains uncompleted due to a complicated geographic mosaic. Some orchid species have restricted ranges as a consequence of the complex geologic history of the island and its numerous barriers to dispersals. One area which should be explored is Cycloops Nature Reserve (Cagar Alam Pegunungan Cycloops, CAPC). It is totally 22.520 ha (SK Mentan No.05/KPTS/UM/1978).

All orchids, epiphytic or terrestrial and autotrophic or heterotrophic heavily dependent on fungi for their existence. It is different with the symbiosis between plant and fungi called AM (arbuscular mycorrhizal), and also ECM (ectomycorrhizal). The role of the fungi is unique, which known to serve as orchids mycorrhiza. Terrestrial orchids, in their habitats require the presence of suitable fungi in the living cells of the plant embryo and development of multicellular absorptive structures in order to develop and mature successfully (Currah et al., 1990)

\footnotetext{
- Corresponding address:

Kampus UNCEN WAENA, Jl. Kamp Wolker, Jayapura 99358

Tel./Fax.: +62-967-572115

email: verena_agustini@yahoo.com.
}

Many researches have been done for mycorrhizal of terrestrial orchids in temperate area, but only a few in tropical area. Mycorrhizal fungi are associated with root systems of more than $90 \%$ of terrestrial plant species in a mutual symbiosis. In nature, all orchids utilize endomycorrhizal fungi to initiate seed germination and seedling development. The availability of each fungi, therefore, is an absolute requirement of orchid life cycle The orchids-fungus symbiosis is initiated when orchid seeds are infected by a suitable fungus (Arditti, 1982; Rasmussen, 1995)

Orchids inoculated by fungi isolated from other plant did not show any positive effect on seedling development (Agustini and Kirenius, 2002). Dendrobium seedling inoculated with orchidmycorrhiza isolated from other orchids shown a better growth than non inoculated one (Agustini, 2003). Most of orchid-mycorrhiza is endomycorrhiza. Fungi associate with photosynthetic orchid mostly belong to subdivision Basidiomycotinae, class Hymenomycetes, genus Rhizoctonia. Otero et al. (2002) reported that among 9 species of Puerto Rican orchids there were 108 Rhizoctonia like fungi which belong to Tulasnella, Ceratobasidium, and Thanatephorus.

Studies by Taylor and Bruns (1997) and Taylor et al. (2004) shown that 17 to 22 fungi species of Russulaceae are associated with Corallorhiza maculata. Limodorum abortivum, an orchid grown in Mediterranean is also associated with fungi belong to family Russulaceae (Girlanda et al., 2006). Russulaceae is basidiomycetes-ectomycorrhizal. 
Orchids of CAPC still remain as one of the least studied (Pokja Cycloops, 2003), therefore some areas such as surrounding Jayapura city, 6 species of terrestrial-orchids were found (Numberi, 2005). Study for the rest of CAPC areas is needed. Because of virtuallyl lack of knowledge in the biodiversity of the mycorrhizal fungi of tropical Orchidaceae, the distribution and identification of fungi from variety of terrestrial orchids were examined. The objectives were to make an inventory of terrestrial-orchids of CPAC area, and to isolate and identify the naturally occurring mycorrhizal fungi of terrestrial orchids from various habitats.

\section{MATERIALS AND METHODS}

The status of orchids-mycorrhiza

Survey on status of orchids-mycorrhiza was done due to determine whether any infection of fungi in the living cells of the roots of the developing orchids or not. Healthy roots of terrestrial-orchids were collected from CPAC areas, namely: (i) UNCEN Campus at Waena (Kamp Walker and Buper), (ii) Sentani (Kemiri and Kampung Harapan), and (iii) downtown city of Jayapura. They were taken, wrapped in tissue paper, put in plastics bag and bring to the laboratory.

\section{Collection and identification of terrestrial orchids}

Sample of terrestrial orchids were collected from various locations of CPAC areas. They were collected ex situ on sterile media due to collect fungi from the orchids. The samples were identified at Botany Laboratory, Cenderawasih University, Jayapura. Some references like Becker and Bakhuizen van den Brink (1963, 1965, 1968); Comber (1990); Segerback (1992); Schuiteman (1995); Mahyar and Sadili (2003); Banks (2004) were used.

\section{Fungal isolation}

The root segment taken from root tip was washed with distilled water to remove any soil. For surface sterilization they were treated with ethanol $70 \%$ for 30 second. The roots were then cut into transverse section about $300 \mu \mathrm{m}$ thick and observed for the presence of hyphal coil (polotons) on a glass slide under a stereo-microscope in sterile condition. Then they were culture onto potato dextrose agar (PDA) media in petridishes, three pieces in each petridish. (Irawati, 2006; pers. comm). Mycorrhizal fungi were isolated using a modification of Masuhara and Katsuya Methods (Manoch and Lohsomboon, 1991). After 1-2 days incubation, the hyphae will grow. If it shows any differences in shape and pattern of growth, then they will be isolated and culture on PDA in order to separate the variety of the fungi. Pure cultures were maintained on PDA slant.

\section{Fungal identification}

Macroscopic features examined were colony growth pattern, color, and mycelia formation. Fungal growth rate was measured from the colony on PDA. For microscopic examination, fertile hyphae were mounted in sterile water on a microscopic slide, covered with a cover slip, and examine under light microscope. Hyphal and monilioid cells were measured. Literatures used in the fungal identification were Sharma et al. (2003) and Athipunyakom et al. (2004).

\section{RESULTS AND DISCUSSION}

\section{Terrestrial orchid species}

Ten terrestrial orchids were found in this study. Among the tenth species, 3 are found in campus areas, seven others are found in Sentani areas (Table 1).

Table 1. The location of terrestrial orchids of CPAC

\begin{tabular}{|c|c|c|}
\hline $\begin{array}{l}\text { No. of } \\
\text { collection }\end{array}$ & Name of species & Location \\
\hline WAE-01 & Spathoglottis plicata L. & Campus \\
\hline WAE-02 & & pus (Buper) \\
\hline SEN-01 & & Sentá \\
\hline SEN-02 & & Sentani (Harapan) \\
\hline WAE-03 & Phaius tankervilleae & Campus \\
\hline VAE-04 & & Can \\
\hline WAE-05 & Geodorum sp. & Campus \\
\hline SEN-10 & & Sentani (Harapan) \\
\hline SEN-04 & Calanthe sp. 1 & \\
\hline SEN-05 & Calanthe s & Sentani (Harapan) \\
\hline SEN-06 & Plocoglottis sp. 1 & \\
\hline SEN-07 & Plocoglottis sp.2 & Sentani (Hara) \\
\hline SEN-08 & Plocoglottis sp.3 & Sentani (Harapan) \\
\hline SEN-09 & Paphiopedilum violascens Schltr. & Sentani (Harapan) \\
\hline JAP-06 & Macodes petola & Jayapura \\
\hline
\end{tabular}

The result is slightly different with Numberi's studied on 2005. She found 6 species of terrestrial orchids growth at city of Jayapura areas including campus surrounding areas. 4 species namely Spathoglottis sp., Phaius sp., Geodorum sp., and Macodes sp. are found in Jayapura surrounding areas.

Two of them Spathoglottis sp. and Geodorum sp. were found in broader areas of study. Spathoglottis sp. can be found in many habitats; from open areas to shading areas in forest either secondary or tertiary. The variety of habitat of Spathoglottis sp. make the flowers have different colors which were identified by Numberi (2005) as different species. It is stated in some literatures that wide ranges of habitat might caused the variety of color of flower.

Among the tenth species, some mycorrhizal fungi has been isolated just from 8 species, fungi from the 2 species remains unisolated. The results of the present study showed that one orchid was associated with a number of mycorrhizal fungi, for example Geodorum densiflorum associated with 6 mycorrhizal fungi; Plocoglottis sp.3 associated with 3 mycorrhizal 
Table 2. Mycorrhizal fungi isolated from terrestrial orchids of CPAC.

\begin{tabular}{|c|c|c|c|c|c|}
\hline $\begin{array}{l}\text { No. of } \\
\text { collection }\end{array}$ & Species & $\begin{array}{l}\text { Mycorrhizal } \\
\text { fungi }\end{array}$ & Habitat & Location & Isolate characteristics \\
\hline \multirow[t]{2}{*}{ WAE-01 } & Spathoglottis sp. & $\begin{array}{l}\text { Rhizoctonia } \\
\text { sp. }\end{array}$ & Open areas & Campus & $\begin{array}{l}\text { On PDA, colony growth slow, } 4,5 \mathrm{~cm} \text { in diameter after } 4 \\
\text { days incubation, thin mycelia, hyalin, globose, hyphae } \\
\text { septate. }\end{array}$ \\
\hline & & $\begin{array}{l}\text { Tulasnella } \\
\text { sp. }\end{array}$ & Open areas & Campus & $\begin{array}{l}\text { On PDA colony growth slowly but faster than } \\
\text { Rhizoctonia sp., mycelium white dense, hyphae } \\
\text { branches. Diameter } 5,5 \mathrm{~cm} \text { after } 4 \text { days incubation. } \\
\text { Hyphae septate, rare, some of hyphae have branches, } \\
\text { upright angles thicken. Conidia globe to ellipsoidal. }\end{array}$ \\
\hline \multirow[t]{6}{*}{ WAE-05 } & $\begin{array}{l}\text { Geodorum } \\
\text { densiflorum }\end{array}$ & Sp. $\left.A^{*}\right)$ & $\begin{array}{l}\text { Shading/ } \\
\text { canopy areas }\end{array}$ & Campus & $\begin{array}{l}\text { On PDA colony growth rapidly, mycelia dense, hyphae } \\
\text { branches rarely, end of hyphae bearing abundant } \\
\text { conidia, globe. }\end{array}$ \\
\hline & & Sp.B *) & $\begin{array}{l}\text { Shading/ } \\
\text { canopy areas }\end{array}$ & Campus & $\begin{array}{l}\text { On PDA colony growth slowly, thin mycelia, hyphae } \\
\text { branching often at nearly upright angles but more } \\
\text { commonly at } 40-60^{\circ}\end{array}$ \\
\hline & & $\begin{array}{l}\text { Ceratorhiza } \\
\text { sp. }\end{array}$ & $\begin{array}{l}\text { Shading/ } \\
\text { canopy areas }\end{array}$ & Campus & $\begin{array}{l}\text { On PDA colony growth slowly, mycelia thin, hyphae } \\
\text { branching, end of hyphae bearing abundant monilloid } \\
\text { cells with typical mode of attachment in a chain 5-6 } \\
\text { globes. }\end{array}$ \\
\hline & & Sp.D *) & $\begin{array}{l}\text { Shading/ } \\
\text { canopy areas }\end{array}$ & Campus & $\begin{array}{l}\text { On PDA colony growth more slowly, dense, circle } \\
\text { growth, black-white. Mycelia thin, septate, abundant } \\
\text { globulus oil. Fungi isolated from terrestrial orchid }\end{array}$ \\
\hline & & Sp.E *) & $\begin{array}{l}\text { Shading/ } \\
\text { canopy areas }\end{array}$ & Campus & $\begin{array}{l}\text { On PDA colony growth slow, circle growth, black and } \\
\text { white. Concentric zonation, mycelia dense, septate } \\
\text { dense, a few number of globulus oil. }\end{array}$ \\
\hline & & Sp.F *) & $\begin{array}{l}\text { Shading/ } \\
\text { canopy areas }\end{array}$ & Campus & $\begin{array}{l}\text { On PDA colony growth slowly. Mycelia hyaline, } \\
\text { branched, single globulus. A few number of coil. }\end{array}$ \\
\hline WAE-03 & Phaius sp. & Sp.G *) & $\begin{array}{l}\text { Shading areas, } \\
\text { next to creek. }\end{array}$ & Campus & $\begin{array}{l}\text { On PDA colony growth rapidly. Hyphae dense, } \\
\text { branches, peloton. Hyphae septate, multinucleate, a } \\
\text { few number of globulus. }\end{array}$ \\
\hline SEN-04 & Calanthe sp.1 & Sp.H *) & $\begin{array}{l}\text { Secondary } \\
\text { forest }\end{array}$ & $\begin{array}{l}\text { Harapan, } \\
\text { Sentani }\end{array}$ & $\begin{array}{l}\text { On PDA colony growth rapidly, densely hyphae, } \\
\text { branches. Characteristics globulus with stem on right } \\
\text { and left of main hyphae. }\end{array}$ \\
\hline SEN-05 & Calanthe sp.2 & Sp.J *) & $\begin{array}{l}\text { Secondary } \\
\text { forest }\end{array}$ & $\begin{array}{l}\text { Harapan, } \\
\text { Sentani }\end{array}$ & $\begin{array}{l}\text { On PDA colony growth rapidly, white until optimal } \\
\text { growth, turn on black color. Diameter } 1 \mathrm{~cm} \text { after } 1 \text { day } \\
\text { incubation, and } 5.5 \mathrm{~cm} \text { after } 5 \text { days of incubation. } \\
\text { Hyphae dense, globulus branches. }\end{array}$ \\
\hline SEN-06 & Plocoglottis sp. 1 & Sp. $\left.I^{*}\right)$ & $\begin{array}{l}\text { Secondary } \\
\text { forest }\end{array}$ & $\begin{array}{l}\text { Harapan, } \\
\text { Sentani }\end{array}$ & $\begin{array}{l}\text { On PDA colony growth rapidly, dense, parallel growth } \\
\text { hyphae, on tip of hyphae abundant granule. }\end{array}$ \\
\hline SEN-07 & Plocoglottis sp.2 & unisolated & $\begin{array}{l}\text { Secondary } \\
\text { forest }\end{array}$ & $\begin{array}{l}\text { Harapan, } \\
\text { Sentani }\end{array}$ & \\
\hline \multirow[t]{3}{*}{ SEN-08 } & Plocoglottis sp.3 & Sp.G *) & $\begin{array}{l}\text { Secondary } \\
\text { forest }\end{array}$ & $\begin{array}{l}\text { Harapan, } \\
\text { Sentani }\end{array}$ & $\begin{array}{l}\text { On PDA colony growth rapidly. Hyphae dense, } \\
\text { branches, peloton. Hyphae septate, multinucleate, a } \\
\text { few number of globulus. }\end{array}$ \\
\hline & & Sp.K *) & $\begin{array}{l}\text { Secondary } \\
\text { forest }\end{array}$ & $\begin{array}{l}\text { Harapan, } \\
\text { Sentani }\end{array}$ & $\begin{array}{l}\text { On PDA colony growth rapidly, white, dense at center, } \\
\text { hyphae thin, branching upright, smaller branches } \\
\text { loosely arrange. Bearing abundant globulus, especially } \\
\text { at the tip of growing hyphae. }\end{array}$ \\
\hline & & Sp.L *) & $\begin{array}{l}\text { Secondary } \\
\text { forest }\end{array}$ & $\begin{array}{l}\text { Harapan, } \\
\text { Sentani }\end{array}$ & $\begin{array}{l}\text { On PDA colony growth slowly after } 15 \text { days of } \\
\text { incubation the color turn in black, concentric zonation, } \\
\text { dense and thin alternately. Mycelia growth fast and } \\
\text { dense. Abundant granular. }\end{array}$ \\
\hline \multirow[t]{2}{*}{ SEN-09 } & $\begin{array}{l}\text { Phapiopedilum } \\
\text { violascens Schltr. }\end{array}$ & Sp.M *) & $\begin{array}{l}\text { Secondary } \\
\text { forest }\end{array}$ & $\begin{array}{l}\text { Harapan, } \\
\text { Sentani }\end{array}$ & $\begin{array}{l}\text { On PDA colony growth rapidly, white, with dense aerial } \\
\text { mycelium in the centre. Hyphae septate, dense, } \\
\text { granular rare. Host: Paphiopedilum violascens Schltr. }\end{array}$ \\
\hline & & Sp.N *) & $\begin{array}{l}\text { Secondary } \\
\text { forest }\end{array}$ & $\begin{array}{l}\text { Harapan, } \\
\text { Sentani }\end{array}$ & $\begin{array}{l}\text { On PDA colony growth rapidly, white, hyphae dense, } \\
\text { branching densely, with abundant globular. Host: } \\
\text { Paphiopedilum violascens Schltr. }\end{array}$ \\
\hline JAP-06 & Macodes sp. & unisolated & $\begin{array}{l}\text { Secondary } \\
\text { forest }\end{array}$ & Jayapura & \\
\hline
\end{tabular}




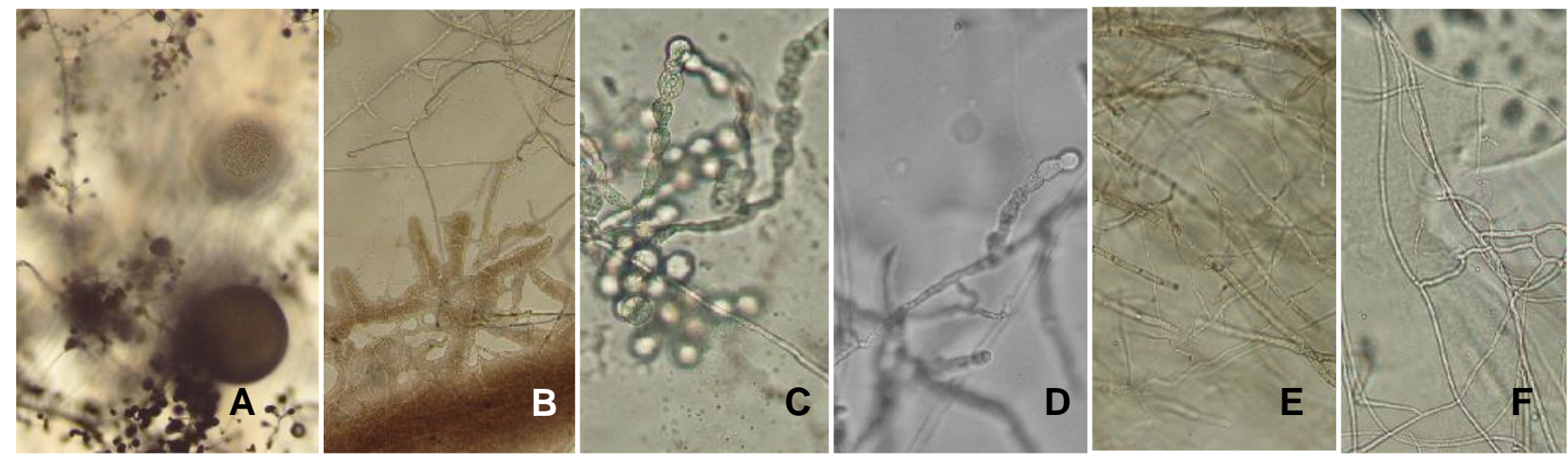

Figure 1. Six isolates taken from the root of terrestrial orchid Geodorum sp.: A. Sp.A, B. Sp.B, C. Ceratorhiza sp., D. Sp.D, E. Sp.E, and F. Sp.F (400x).
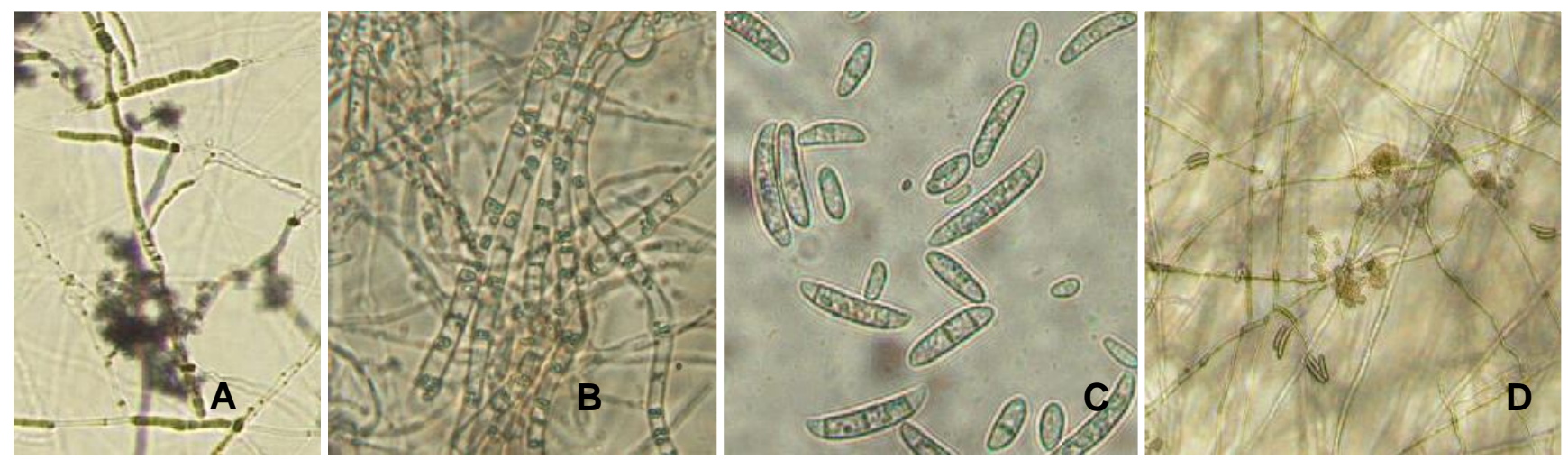

Figure 2. Reproductive portion of mycorrhiza. A. Hyphae of Rhizoctonia sp. 4 days on PDA. 400 x. B. Hyphae Sp.G taken from Phaius sp., septate, multinucleate, globulus oil, 1000x. C. Conidia of Tulasnella sp., 400 x. D. Hyphae supporting conidiospores, 100x.
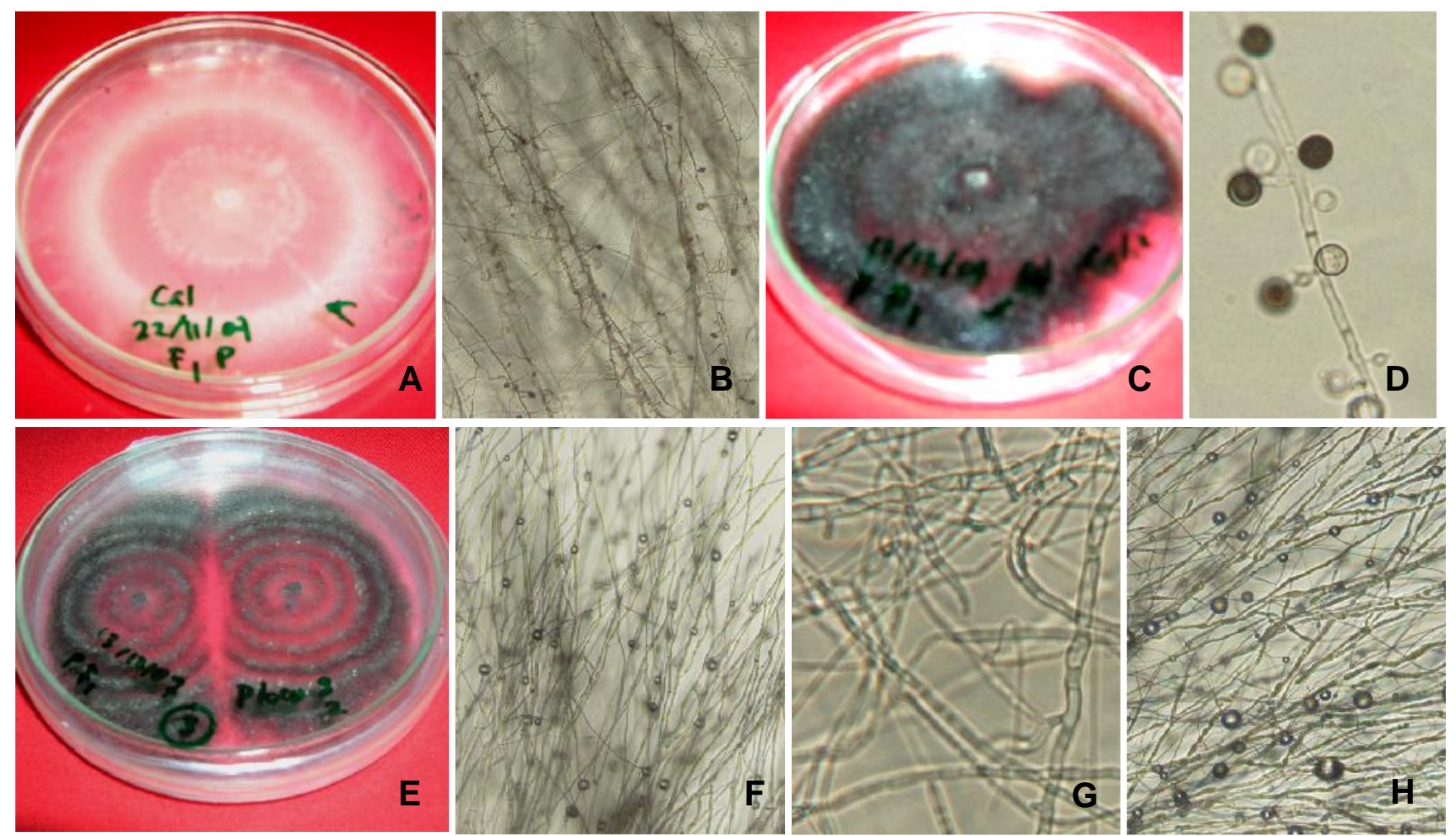

Figure 3. Colony of mycorrhiza. A. Sp.I: colony on PDA showing concentric zonation, 100x; B. Sp.I: abundant granule on tip of hyphae, 100x; C. Sp.J: colony on PDA; D. Sp.J: branches hyphae with globulus, 400x; E. Sp.L: colony on PDA showing concentric zonation and black in color after 15 days incubation; F. Sp.L: hyphae with abundant granule, 100x; G. Sp.M: dense and septate hyphae with few granule, 1000x; H. Sp.N: dense and branching hyphae with abundant granule, 100x. 
fungi (sp.G, sp.K, and sp.L); Spathoglottis and Paphiopedilum violascens associated with 2 mycorrhizal fungi each. The study also found that a number of mycorrhizal fungi were associated with a single orchid host, for instance Rhizoctonia sp. and Tulasnella sp. are associated with Spathoglottis whereas Mycorrhizal fungi sp.M and sp.N are associated with Paphiopedilum violascens (Figure 3).The other orchids are associated with single fungus. This study indicated that mycorrhiza sp.G was isolated from Phaius sp. and also from Plocoglottis sp.3.

This study showed that from the two orchids Plocoglottis sp.2 and Macodes sp., mycorrhizal fungi remained unisolated. There are 17 mycorrhizal fungi isolated from 8 orchids of CPAC areas (Table 2). Athipunyakom et al. (2004) did a similar study, and found 14 mycorrhizal fungi from eleven terrestrial orchids in Thailand, among them are Rhizoctonia globularis, Ceratorhiza sp., and Tulasnella sp.

\section{Association of mycorrhiza and terrestrial orchid}

The results of the study shown that a number of mycorrhizal fungi were associated with only one orchid. There were six mycorrhizal fungi associated with Geodorum sp. (Figure 1). Rhizoctonia sp. and Tulasnella sp. are symbiont of Spathoglottis.(Figure 2). According to Athipunyakom et al. (2004), Tulasnella sp. Is also associated with Cymbidium tracyanum, in root of Calanthe sp. was found fungi Epulorhiza and Ceratorhiza, while in this study Ceratorhiza fungi were isolated from Geodorum sp. Fungi sp.G are associated with both Phaius and Plocoglottis sp.3. Kristiansen et al. (2004) also found a similar situation that many fungi were associated with one specific orchid.

Almost all mycorrhiza associated with terrestrial orchid is Rhizoctonia including anamorphic of Tulasnella, Ceratobasidium, and Thanatephorus (Otero et al., 2002; Bonnardeaux et al., 2007). Fungi known to be associated with Spathoglottis sp. is Rhizoctonia, similar to study done by Tan et al. (1998) using terrestrial orchid Spathoglottis plicata. He inoculated Rhizoctonia AM9 on the media to germinate seed. The study showed that there is important role of the fungi on Spathoglottis plicata seed germination. Hayakawa et al. (1999) showed different results, there was no significant effect of the isolate on in vitro seed germination.

In contrast, this study indicated that one fungi merely associated with a single orchid host. Calanthe sp.1 and Sp.H and Calanthe sp.2 and Sp.J which both remained unidentified (Table 2). Study of symbiosis of fungi and orchid is extremely unique, mainly Pterostylis, Caladenia and Thelymitra. These fungi grow in very close habitat but they have different host, namely Ceratobasidium, Sebacina and Tulasnella (Andersen and Rasmussen, 1996). The Fungi Rhizoctonia is known as a symbiont of Spathoglottis sp, and is found in Pinus radiata root as well. Furthermore, Bidartondo et al. (2004), reported that orchids grow under canopy can be associated both with fungi mycorrhiza and trees at the surrounding habitat. Fungi which are associated with orchid are basidiomycetes. Some of them are saprophytic, ectomycorrhiza, and plant parasitic (Rasmussen, 2004), while Yamato et al. (2005) said that achroroplilous Epipogium roseum also known associated with Coprinus which is saprophytic fungi.

The specific relationship between fungi and orchid also reported by Rasmussen (2004). The specificity was found from taxon species to subtribe (Warcup, 1981). Photosynthetic orchids showed a high specificity in association of mycorrhizal-orchids (Shefferson et al., 2005). Specificity possibly leads to high rates of orchid seed germination and a more efficient physiological association when the interaction is fully functional (Bonnardeaux et al., 2007). Mycoheterotrophic orchid Corallorhiza maculata was associated with twenty two fungi belong to family Russulaceae which is ectomycorrhizal in plants (Taylor et al., 2004).

In this study, transversal root segments of terrestrial orchids were used as a source of mycorrhizal fungi, this method were also used by Shan et al. (2002) and Bonnardeaux et al. (2007). Other isolates source of orchids-fungi were hyphal coils (peloton) taken from longitudinal sections of roots (Athipunyakom et al., 2004; Bonnardeaux et al., 2007).

\section{CONCLUSION}

Ten terrestrial orchids were found in Cagar Alam Pegunungan Cycloops, Jayapura. From eight of the ten orchids there were seventeen mycorrhizal orchids, three of them are identified as Rhizoctonia sp., Tulasnella sp., and Ceratorhiza sp. Dari Among them six fungi isolated from a single orchid Geodorum $\mathrm{sp}$. In this study the specificity was found in most mycorrhizal-fungi except Sp.G which found in two different terrestrial orchid species namely Phaius sp. and Plocoglottis sp.

\section{ACKNOWLEDGEMENTS}

We thank to the Directorate General of Higher Education, Ministry of National Education through Fundamental Research Grant, 2007 and Indonesia Managing Higher Education for Relevance and Efficiency Project (I-MHERE Project) Sub-Component B.1. Batch II, through Research Grant Program 2007 for financial support, and we also would like to thank to Ira Aldila Putri and Dewi Katemba for their laboratory work. 


\section{REFERENCE}

Arditti, J. 1982. Orchid seed germination and seedling culture-A manual. In: Arditti, J. (ed.) Orchid Biology: Reviews and Perspectives II. London: Cornell University Press.

Agustini, V. 2003. Peranan mikoriza-anggrek pada pertumbuhan anggrek Dendrobium sp. Sains 3 (2): 39-42.

Agustini, V. dan M. Kirenius. 2002. Pengaruh mikoriza pada pertumbuhan dan perkembangan awal anggrek Dendrobium sp. Sains 2 (2): 55-60.

Andersen, T.F. and H.N. Rasmussen. 1996. The mycorrhizas species of Rhizochtonia. In: Sneh, B., S. Jabaji-Hare, S. Neate and G. Dijst (eds.). Rhizoctonia Species: Taxonomy, Molecular Biology, Ecology, Pathology and Disease Control. London: KAP.

Athipunyakom, P., L. Manoch, and C. Piluek. 2004. Isolation and identification of mycorrhizal fungi from eleven terrestrial orchids. Natural Science 38 (2): 216-228.

Backer, C.A and R.C. Bakhuizen van de Brink, Jr. 1963. Flora of Java. Vol. 1. Groningen: Wolter-Noordhoff N.V.

Backer, C.A and R.C. Bakhuizen van de Brink, Jr. 1965. Flora of Java. Vol. 2. Groningen: Wolter-Noordhoff N.V.

Backer, C.A and R.C. Bakhuizen van de Brink, Jr. Flora of Java. Vol. 3. Groningen: Wolter-Noordhoff N.V.

Banks, D.P. 2004. Orchid Grower's Companion: Cultivation, Propagation, and Varieties. Portland, Or.: Timber Press.

Bidartondo, M.I., B. Burghardt, G. Gebaner, T.D. Bruns, and D.J. Read. 2004. Changing partners in the dark: isotopic and molecular evidence of ectomycorrhizal liaisons between forest orchids and trees. Proceeding of Biological Science 271 (1550): 1799-1805

Bonnardeaux, Y., M. Brundrett, A. Batty, K. Dixon, J. Kock, and K. Sivasithamparam. 2007. Diversity of mycorrhizal fungi of terrestrial orchid: compatibility webs, brief encounters, lasting relationships and alien invasion. Mycological Research 111 51-61.

Comber, J.B. 1990. Orchid of Java. London: Royal Botanic Gardens Kew, England.

Girlanda, M., M.A. Selosse, D. Cafasso, F. Brilli, S. Defline, R. Fabbian, S. Ghignone, P. Pinelli, R. Segreto, F. Loreto, S Cozzolino, and S. Perotto. 2006. Inefficient photosynthetis in the Mediterranean orchids Limodorum abortivum is mirrored by specific association to ectomycorrhizal Russulaceae. Molecular Ecology 15 (2): 491-504.

Hayakawa, S., Y. Uetake, and A. Ogoshi. 1999. Identification of symbiotic rhizoctonias from naturally occuring protocorms and roots of Dactylorhiza aristata (Orchidaceae). Journal of Faculty of Agriculture, Hokkaido University 69 (2): 129-141.

Kristiansen K.A., J.V. Freudenstein, F.N. Rasmussen, H.N Rasmussen. 2004. Molecular identification of mycorrhizal fungi in Neuwiedia veratrifolia (Orchidaceae). Mol Phylogenet Evol. 33 (2): 251-258.

Mahyar, W. dan A. Sadili. 2003. Jenis-jenis anggrek Taman Nasional Gunung Halimun. Bogor: LIPI-JICA-PHKA.

Manoch, L. and P. Lohsomboon. 1991. Isolation of mycorrhizal fungi from orchid roots. ASEAN Regional Training Course on Mycorrhiza. SEAMEO BIOTROP \& Chiang Mai University. Chiang Mai, 17-19 March 1991.

Numberi, A. 2005. Jenis-Jenis Tanaman Anggrek Terestrial di Kotamadya Jayapura. [Skripsi]. Jayapura: FMIPA Universitas Cenderawasih.

Otero, J.T., J.D. Ackerman and P. Bayman. 2002. Diversity and host specificity of endophytic Rhizoctonia-like fungi from tropical orchids. American Journal of Botany 89 (11): 18521858.

Pokja Cycloops. 2003. Potret Penataan Hutan Kawasan Cagar Alam Cycloops. Jayapura: WWF.

Rasmussen, H.N. 2004. Recent development in the study of orchid mycorrhiza. Plant and Soil 244 (1): 149-163.

Schuiteman, A. 1995. Key to the genera of Orchidaceae of New Guinea. Flora Malesiana Buletin 11 (6): 401-424.

Segerback, L.B. 1992. Orchid of Malaya. Rotterdam: A.A. Balkema Publisher.

Shan, X.C., E.C.Y. Liew, M.A. Weatherhead, and I.J. Hodgkiss. 2002. Characterization and taxonomic placement of Rhizoctonia-like endophytes from orchid roots. Mycologia 94 (2): $230-239$

Sharma, J., L.W. Zettler, and J.W. van Sambeek. 2003. A Survey of mycobionts of federally threatened Platanthera praeclara (Orchidaceae). Symbiosis 34: 145-155.

Shefferson, R.P., M. Weib, T. Kull, and D.L. Taylor. 2005. High specificity generally characterizes mycorrhizal association in rare lady's slipper orchids, genus Cypripedium. Molecular Ecology 14 (2): 613-621.

SK Mentan No. 05/KPTS/UM/1978 tentang Penentuan Kawasan Konservasi Cagar Alam Cycloops.

Tan, T.K., W.S. Loon, E. Khor, and C.S. Loh. 1998. Infection of Spathoglottis plicata (Orchidaceae) seeds by mycorrhizal fungus. Plant Cell Reports 18: 14-19.

Taylor, D.L., and T.D. Bruns. 1997. Independent, specialized invasions of ectomycorrhizal mutualism by two nonphotosynthetic orchids. Proceeding of the National Academic of Science of the USA 94 (9): 4510-4515

Taylor, D.L., T.D. Bruns, and S.A. Hodges. 2004. Evidence for mycorrhizal races in a cheating orchid. Proceeding of Biological Science 271 (1534): 35-43.

Yamato, M., T. Yagame, A. Suzuki, and K. Iwase. 2005. Isolation and identification of mycorrhizal fungi associating with an achlorophyllous plant, Epipogium roseum (Orchidaceae). Mycoscience 46 (2): 73-77.

Warcup, J.H. 1981. The mycorrhizal relationships of Australian orchids. New Phytologist 87: 371-381. 